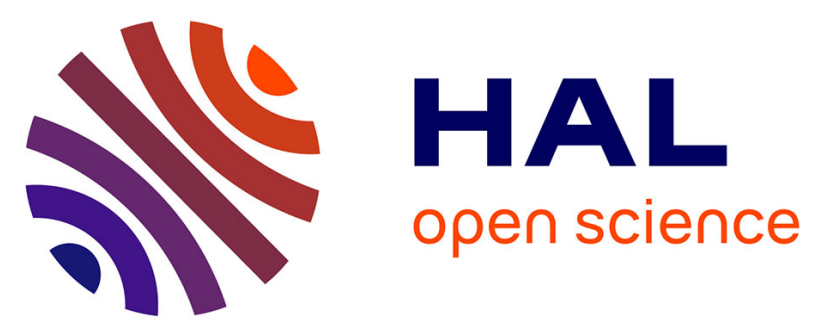

\title{
Assessing the Ability to Communicate in Self-archiving Interfaces
}

María Inés Laitano

\section{To cite this version:}

María Inés Laitano. Assessing the Ability to Communicate in Self-archiving Interfaces. 8th Latin American Conference on Human-Computer Interaction, Nov 2017, Antigua, Guatemala. 10.1145/3151470.3156637 . halshs-01907124

\section{HAL Id: halshs-01907124 https://shs.hal.science/halshs-01907124}

Submitted on 28 Oct 2018

HAL is a multi-disciplinary open access archive for the deposit and dissemination of scientific research documents, whether they are published or not. The documents may come from teaching and research institutions in France or abroad, or from public or private research centers.
L'archive ouverte pluridisciplinaire HAL, est destinée au dépôt et à la diffusion de documents scientifiques de niveau recherche, publiés ou non, émanant des établissements d'enseignement et de recherche français ou étrangers, des laboratoires publics ou privés. 


\section{Assessing the Ability to Communicate in Self-archiving Interfaces}

María Inés Laitano

LabSic, Université Paris 13

99 Avenue Jean Baptiste Clément

93430 Villetaneuse, France

mariaines.laitano@univ-paris13.fr
Permission to make digital or hard copies of part or all of this work for personal or classroom use is granted without fee provided that copies are not made or distributed for profit or commercial advantage and that copies bear this notice and the full citation on the first page. Copyrights for third-party components of this work must be honored. For all other uses, contact the Owner/Author.

CLIHC '17, November 8-10, 2017, Antigua Guatemala, Guatemala (C) 2017 Copyright is held by the owner/author(s).

ACM ISBN 978-1-4503-5429-5/17/11.

https://doi.org/10.1145/3151470.3156637

\author{
Abstract \\ Open access repositories (OAR) are becoming \\ increasingly important and it becomes necessary to \\ improve self-archiving interfaces to increase deposits \\ made by their authors. This paper evaluates the \\ DSpace self-archiving interface with the Trifocal \\ framework to propose communication improvements \\ and to show that assessing the interface's ability to \\ communicate reports improvements mainly related to \\ the application domain.
}

\section{Author Keywords}

Trifocal framework; Evaluation framework; DSpace;

Open Access Repositories; Self-archive.

\section{ACM Classification Keywords}

H5.2 [Information interfaces and presentation]: User Interfaces - Evaluation/Methodology

\section{Introduction}

Open access repositories (OAR) are priority instruments in Latin American policy [10] to disseminate the intellectual production of educational, scientific and governmental organizations. Getting authors to selfarchive their outputs is critical to ensuring the OAR growth and sustainability, especially in those archives that do not have dedicated staff. The Latin American 
HCI community thus has the challenge of improving submission interfaces to increase deposits in OAR.

This paper evaluates the DSpace self-archiving interface (the most used software to implement OAR) with the Trifocal framework [8]. Its contribution is twofold:

1. It proposes communication improvements for the DSpace self-archiving interface that were reported and accepted in the DSpace Issue Tracking System. As DSpace is a turnkey software, improvements in the generic version result in beneficial improvements for all the institutions that install it.

2. It shows that assessing the interface's ability to communicate reports improvements mainly related to the application domain. This type of evaluation can complement classic usability assessments as well as encourage new directions in interfaces evaluation research.

\section{Related work}

While there is a long tradition in evaluating Digital Libraries interfaces and especially Information Retrieval processes, only a few works focus on OAR and are concentrated on assessments of authors' activities on self-archive [4]. There are also few heuristic evaluations of OAR interfaces and assessments of DSpace interfaces. The most common methods for evaluating repository interfaces are user studies $[1,3,5,11]$ and questionnaires $[3,6,12]$.

In general, the analyzed aspects are classic usability criteria such as effectiveness, efficiency, supportiveness, usefulness or satisfaction $[1,3,4,6,7,12]$. Only a few [2] study domain-specific criteria such as legal aspects (copyright information, authorization for content distribution), policy (what can be deposited and in what format), update (latest articles, number of records), etc.

\section{Applying the Trifocal framework}

The Trifocal framework [8] is a three-tier heuristic framework for assessing the interface's ability to communicate. It integrates several HCI trends in order to evaluate interfaces in a holistic way [9]. The first level is that of enunciation. It examines the communication between interface designers and his audience. Designers do not only designate the direct producers of the interface but also anyone who pursues an objective through its creation. The audience is the group of potential users. In the case of self-archiving interfaces, the designers would be the managers, technicians and librarians of the institution that hosts the OAR. The audience would be composed of academics or individuals who produce content suitable for the OAR. At the enunciation level, the Trifocal framework proposes to inspect the designer's discourse, how the designer presents himself, what values he exhibits, and how he influences his audience. In the case of self-archiving interfaces, designers will seek to persuade the authors to submit their works with the ultimate purpose of growing the OAR.

The second level is that of activity. It examines the objects of the world with which the user interacts and the activities to which these objects give rise. Propositions to interact with these objects and representations of the user's actions on these objects are identified at the activity level. In the case of selfarchiving interfaces, there are activities such as choosing a collection to submit, granting distribution 
permission, choosing a license type, uploading file(s), describing the publication and reviewing the submission. And an interaction proposal is, for example, the checkbox that follows the distribution permission text. The representation of the user action is the marked checkbox.

The third level is that of access. It analyzes the manipulations that the user makes on the technological artifacts. The technological artifacts (PC, mobile, TV, etc.) must be identified a priori because the interface representations diverge according to each. Then, for each activity identified in the previous level, the Trifocal framework observes which peripherals of the artifact are involved (mouse, keyboard, screen, etc.), what propositions to interact are made to the user and how the user actions on them are represented.

\section{DSpace interesting findings}

Below are illustrated a number of opportunities for improvement that arise from assessing the DSpace self-archiving interface (demo.dspace.org/xmlui/) through the Trifocal framework.

\section{Enunciation level}

The dynamic and influential character of the OAR can be highlighted with visualizations of statistical data on the home page (number of records per type of submission, number of reads and downloads, etc.). Reliability can be increased by linking to the Sherpa / Romeo website on the first page of the submission process that allows authors to check the publishers' self-archiving policy. The listening attitude of designers can be promoted with a telephone contact displayed on every page of the self-archiving process.

\section{Activity level}

Most of propositions to interact are made with the text of links, buttons, titles, etc. The text should show exactly the activity or object it represents ('Step 1 of 8: Classification' instead of 'Item submission', 'Your submissions' instead of 'Submissions'), it should use user's vocabulary ('Publication' instead of 'Item') and should avoid technical terms ('Sign in' instead of 'Log in'). When several activities coexist on the same page, the main activity should be distinguished from the secondary ones. E.g. titles and buttons of 'New deposit' main activity should use green and secondary menu options should use blue. To highlight an activity among others, the size can be used. E.g. a large 'New submission' button instead of the 'Start another submission' link on the 'Submissions' page. Elements that correspond to the same object in the world can be grouped: fields 'last name' and 'name' in a fieldset 'author'. Conventions and habits of each activity should be respected. E.g. entering publication keywords as a list of words separated by commas or semicolons. Finally, the user should know that his action was successful. E.g. when uploading the file show a thumbnail in the list of uploaded files.

\section{Access level}

The evaluation was done with a standard notebook. It was found, for example, that the interaction proposal of drop-down lists (the invitation to display it with a click) could, in hover, change the cursor shape to a hand, color the border of the drop-down list and delete the tooltiptext that is redundant with the instructions. To invite to retract the list the direction of the arrow should be inverted. 


\section{Conclusion}

The last two sections presented briefly: the application of the Trifocal framework to the OAR self-archiving process as well as communication improvements that result from this application on the DSpace interface. This improvements, especially at enunciation and activity levels, are mainly related to the OAR domain and can complement classic usability improvements.

\section{References}

1. Maha Aljohani and James Blustein. 2015. Heuristic Evaluation of University Institutional Repositories Based on DSpace. Design, User Experience, and Usability: Interactive Experience Design, Springer, Cham, 119-130.

2. Anabel Bonilla-Calero. 2013. Good practice in an institutional repository service: case study of Strathprints. Library Review 62, 6/7: 429-436.

3. Roberta Caccialupi, Licia Calvi, Maria Cassella, and Georgia Conte. 2009. Usability Evaluation of a Multimedia Archive: B@bele. In Research and Advanced Technology for Digital Libraries. Springer Berlin Heidelberg, 370-376.

4. Q. Feng and R. Huang. 2008. Evaluating the usability of discipline repositories. IEEE International Symposium on IT in Medicine and Education, 2008. ITME 2008, 385-390.

5. Fereshteh Afshari and Richard Jones. 2007. Developing an integrated institutional repository at Imperial College London. Program 41, 4: 338-352.
6. Georgios Gkoumas and Fotis Lazarinis. 2015. Evaluation and usage scenarios of open source digital library and collection management tools. Program 49, 3: 226-241.

7. Hyun Hee Kim and Yong Ho Kim. 2008. Usability study of digital institutional repositories. The Electronic Library 26, 6: 863-881.

8. María Inés Laitano. 2015. Le modèle trifocal : une approche communicationnelle des interfaces numériques. Retrieved from https://tel.archivesouvertes.fr/tel-01218246.

9. María Inés Laitano and Philippe Bootz. 2017. Design d'interfaces: du dialogue homme-machine au support médiatique. MEI - Médiation et information.

10. Alejandra Naser, Álvaro Ramirez-Alujas, and Daniela Rosales, eds. 2017. Desde el gobierno abierto al Estado abierto en América Latina y el Caribe. CEPAL, Santiago.

11. Isaias Barreto da Rosa and David Ribeiro Lamas. 2012. Designing Mobile Access to DSpace-based Digital Libraries. Proceedings of the International Working Conference on Advanced Visual Interfaces, ACM, 745-748.

12. Giannis Tsakonas and Christos Papatheodorou. 2008. Exploring usefulness and usability in the evaluation of open access digital libraries.

Information processing \& management 44, 3: 12341250. 